\section{The relationship between nutrient intake, dental status and family cohesion among older Brazilians}

\author{
Relação entre ingestão de nutrientes, condição \\ dental e coesão familiar em idosos brasileiros
}

\footnotetext{
${ }_{1}^{1}$ Faculdade de Odontologia, Universidade de Pernambuco, Recife, Brasil.

2 Centro de Ciências da

Saúde, Universidade Federal

de Pernambuco, Recife,

Brasil.

3 Faculdade Salesiana de Vitória, Vitória, Brasil.

4 Centro de Ciências Exatas, Universidade Federal do Espírito Santo, Vitória, Brasil.

Correspondence

F. B. Andrade

Faculdade de Odontologia,

Universidade de Pernambuco.

Rua Waldir Dutra de Freitas

120, Vitória, ES 29066-280,

Brasil.

fabiolabof@yahoo.com.br
}

\section{Abstract}

The aim of this study was to investigate the relationship between inadequate nutrient intake, oral health and family cohesion. This was a crosssectional study with a sample of 887 non-institutionalized elderly people from Vitória, Espírito Santo State, Brazil. Oral examination was performed by trained and calibrated examiners and three measurements were considered: number of posterior occluding pairs of natural teeth (POP), number of teeth and overall dental status. Nutrient intake was assessed by a 24-hour diet recall interview. The elderly person's perception of family cohesion was assessed using the family adaptability and cohesion scale. People with no POP were more likely than those with 5 or more POP to have inadequate intake of vitamin $C(O R=2.79$; 95\%CI: 1.16-6.71), calcium (OR $=3.74 ;$ 95\%CI: 1.69-8.25), riboflavin (OR $=2.49 ; 95 \% C I: 1.10$ 5.64) and zinc (OR = 3.43; 95\%CI: 1.07-10.94). There was no association between elderly people's perceptions of family cohesion and inadequate intakes. It was concluded that oral health is related to inadequate intake of important nutrients among non-institutionalized elderly people.

Oral Health; Nutrition; Aged; Social Support
Fabiola Bof de Andrade 1 Arnaldo de França Caldas Junior 2 Pedro Makumbundu Kitoko ${ }^{3}$ Eliana Zandonade 4

\section{Introduction}

Preventing disease in older people is an important health objective, and diet plays a primary role in achieving this goal 1,2,3,4,5. Several studies have shown that general health, quality of diet and nutrient intake are determined by multiple factors 6,7 including social support $8,9,10$, socioeconomic status, culture 7,11 and oral health 12,13.

Regarding oral health, current studies show an association between dental status and the mean intake of nutrients 12,13. An increase in dental impairment (e.g. edentulism, lack of prosthetic rehabilitation and lack of posterior occluding pairs of teeth) is associated with a decrease in the mean intake of vitamin $\mathrm{C}$, vitamin A, calcium, fiber and protein 12,14. Previous studies have focused on identifying the relationship between oral health and mean nutrient intake or food choice, though few have investigated how much these associations within the groups represent in terms of inadequacy of nutrient intake, since the prevalence of inadequate intake of important nutrients is high among elderly people 15,16 .

An increasing amount of evidence shows that social support has a positive influence on dietary habits 17,18 and health status 9,19. According to the literature, family and friends are an important source of instrumental and emotional support, especially for older people 20,21. Family cohesion, which is defined as the emotional bond- 
ing between family members, is a key domain for family functioning 22 and is also related to an individual's health 23 . In spite of this, there is a lack of studies that explore the relationship between family cohesion and the health of older people 23 , and hardly any studies have evaluated the association between this factor and adequate nutrition in older populations. Because nutrition has a strong influence on an older person's health (particularly on their level of frailty) 24,25, the aim of this study was to investigate the relationship between nutrient intake, oral health and family cohesion. The hypothesis of the study was that impaired dentition and unbalanced families would be associated with an inadequate nutrient intake.

\section{Methods}

The cross-sectional data used in this study were derived from a larger study on the nutrition and oral health of independent-living people aged 60 and over, that took place in the city of Vitória, the capital of Espírito Santo State, southeast Brazil, from April to September, 2006. The sample consisted of older people who were randomly selected from the Family Health Program (FHP) and Community Agents Health Program (CHAP), as published earlier 13. The sampling was made by clusters in three stages: in the first stage the districts were selected, in the second, the microareas and in the third stage, the elderly. The individuals who were physically and/or mentally unable to undergo the examinations were excluded. The exclusion was based on the information from the records of the FHP. In this study 1,000 elderly were randomly selected considering a possible loss ranging from $20 \%$ or more. This sample size has a statistical power greater than $80 \%$ for all hypotheses tested (bi-and multivariate models) for odds ratio values greater than or equal to 2 . All subjects who had complete data about their dietary intake and oral health were included in the analysis.

Data was collected at the participants' homes and included an interviewer-administered structured questionnaire, oral health examination and dietary assessment. Sociodemographic data included their age, gender, marital status, schooling of the elderly, schooling of the head of household, size of the household and number of children. Smoking status and exercise practice were chosen as lifestyle markers. With regard to chronic diseases, subjects were considered to be hypertensive or diabetic if they reported current use of anti-hypertensive or hypoglycemic agents.
The older person's perception of family cohesion was assessed using the Family Adaptability and Cohesion Scale (FACES III) 26. This measurement assesses the degree to which family members are separated from or connected to their family. There are four levels of cohesion: disengaged, separated, connected and very connected 26. The central levels (separated or connected) are considered to be balanced levels of family cohesion and the extremes (disengaged or very connected), unbalanced levels 22 .

Oral examination was carried out in accordance with World Health Organization (WHO) criteria 27 by four trained and calibrated examiners. The kappa index ranged from 0.75 to 0.99 and from 0.88 to 0.96 for the intraexaminer agreement with regard to the number of posterior occluding pairs of teeth and number of teeth, respectively. The interexaminer agreement ranged from 0.72 to 0.88 and from 0.83 to 0.89 , for the number of posterior occluding pairs of teeth and number of teeth, respectively. During the study each dentist reexamined $10 \%$ of the patients in order to check the reliability of the data, and the kappa index ranged from 0.68 to 1.0 for the number of posterior occluding pairs of teeth and from 0.79 to 0.94 for the number of teeth.

Data regarding the number of teeth and presence of dental prostheses were used to generate three measures of oral health: the number of natural teeth; the number of posterior occluding pairs of natural teeth (POP) 28 - contacts between natural teeth and the pontics of fixed bridges only - and overall dental status. The latter was categorized into five groups according to the number of natural teeth and use of dental prostheses: (1) complete dentures, defined as use of two complete dentures; (2) partial dentures, defined as use of two partial dentures; (3) mixed condition, defined as use of one partial denture, one complete denture or both; (4) complete natural dentition, defined as 24 or more natural teeth without use of a partial denture; (5) incomplete natural dentition, defined as less than 24 natural teeth without use of partial or complete dentures.

Detailed information on dietary intake was assessed using two 24 -hour diet recalls in a structured face-to-face interview with standardized neutral probing questions. These were carried out on non-consecutive days. This is a reliable instrument for epidemiological studies because it is easy to use, even when the interviewees have a low level of schooling 29,30. It is also inexpensive, so it can be used in low-income countries. The uses, limitations, reliability and validity of this method have been discussed and reported previously 29 . The data from these records were converted to nutritional intake data using the $\mathrm{Di}$ - 
etpro version 4.0 software (http://www.dietpro. com.br; A.S. Sistemas, Viçosa, Brasil).

Ten nutrient intakes were compared with age and gender-specific Dietary Reference Intakes from the Food and Nutrition Board of the National Academy of Science. As in other studies $3,15,31$, inadequate nutrient intake was defined as an intake lower than $67 \%$ of the adequate intake for calcium 32 and lower than $67 \%$ of the Reference Dietary Allowance for phosphorus 32, vitamin C 33 , iron 34 , carbohydrate, protein 35 , zinc, niacin, riboflavin and thiamin 36 . In addition (since all nutrients are important for health) the mean number of nutrients consumed at adequate levels was also calculated as a way of assessing overall nutritional adequacy.

The statistical analysis included descriptive and inferential analyses, using a 5\% significance level and 95\%CI. Differences between means were assessed using the Student's t test or ANOVA, followed by multiple comparison analysis. Associations between categorical variables were tested using chi-squared or likelihood ratio analyses. The dependent variables of the study were the mean number of nutrients consumed at an adequate level and the intake of each nutrient. All independent predictor variables that were statistically significant $(\mathrm{p}<0.10)$ in the bivariate analysis were entered into a multivariate model. Multiple logistic regression was carried out to find out the relationship between inadequate nutrient intake and the independent variables (socioeconomic, lifestyle, oral health measurements and family cohesion) using a forward stepwise (logistic regression) method. Differences between the mean number of nutrients that were consumed adequately and the independent variables (socioeconomic, lifestyle, oral health measurements and family cohesion) were tested using multiple linear regression with a stepwise method. Data were tabulated using Epi Info 6.04 (Centers for Disease Control and Prevention, Atlanta, USA) and were converted for analysis using the SPSS version 15.0 software (SPSS Inc., Chicago, USA).

This study was approved by the Ethics in Research Commission of the University of Pernambuco. Written informed consent was obtained from the subjects.

\section{Results}

The main study consisted of $887(88,7 \%)$ older people, 816 of whom had complete information regarding oral health status. Details regarding sampling size are shown in Figure 1.

About $67 \%$ of subjects were female and the age range was 60 to 101 years (median, 70 years).
Most were married (48.2\%), 33.5\% were widowed and the majority had two or more children $(84.7 \%)$. In relation to the lifestyle markers, the majority (69.1\%) did not practice exercise and did not smoke (91.3\%). Regarding schooling, the majority had a low level; $51.3 \%$ were illiterate or had less than 4 years, $25.1 \%$ had $4-7$ years, $11.0 \%$ had 1-14 years and only $4.8 \%$ had 15 or more years. With regard to the size of the household, the majority $(76.2 \%)$ lived in a house with $2-5$ people, $12.2 \%$ lived in a house with more than 6 people and only $11.6 \%$ lived alone.

The prevalence of inadequate nutrient intake was high (above $80 \%$ for most nutrients). The most adequately consumed nutrients were vitamin C, iron, protein and carbohydrates $(44.8 \%$, $15.9 \%, 14.6 \%$ and $6.4 \%$ of inadequacy, respectively). The mean number of nutrients consumed at an adequate level was 3.75 (median 4.00), and $23.6 \%$ of the sample had an adequate nutrient intake of five or more nutrients.

In relation to dental status, $12.3 \%$ of the elderly people had 21 or more teeth; $25.9 \%$ had one to 10 teeth and $17.3 \%$ had between 11 and 20 teeth. Regarding the number of POP, $79.5 \%$ had no POP, $12.4 \%$ had 1 to 4 POP and only $8.1 \%$ had 5 or more POP. Considering dental status, $29 \%$ had complete dentures, $5.4 \%$ used partial dentures, $39.6 \%$ had mixed condition, $5.1 \%$ had complete dentition and $20.8 \%$ had incomplete dentition.

According to the results, family cohesion was perceived as being balanced for the majority of participants (separated and connected, 28.3\% and $29.8 \%$, respectively). About $27.2 \%$ were classified as disengaged and $14.6 \%$ as very connected. The bivariate analysis revealed that neither the mean number of nutrients consumed at adequate level nor the inadequacy of nutrient intake were related to family cohesion. This was not included in the multivariable analysis for any of the nutrients studied. Conversely, inadequate intake of all nutrients, except for riboflavin and carbohydrate, was significantly associated $(\mathrm{p}<0.05)$ with at least two of the oral health variables that were included in the multiple logistic regression model. The intake of riboflavin was only associated to the POP (0.023) and there was no statistic significance between carbohydrate inadequacy and dental status ( $\mathrm{p}>0.05)$.

Table 1 shows a summary of the final logistic regression model for inadequate intake of the ten nutrients studied in relation to the independent variables that remained statistically significant. Gender was associated with 7 out of the $10 \mathrm{nu}-$ trients studied, schooling of the elderly (years) was related to 5 nutrients and POP was related with 4 nutrients. Table 2 shows the odds ratio of inadequacy of nutrient intake for all nutrients ac- 
Figure 1

Sample size details.

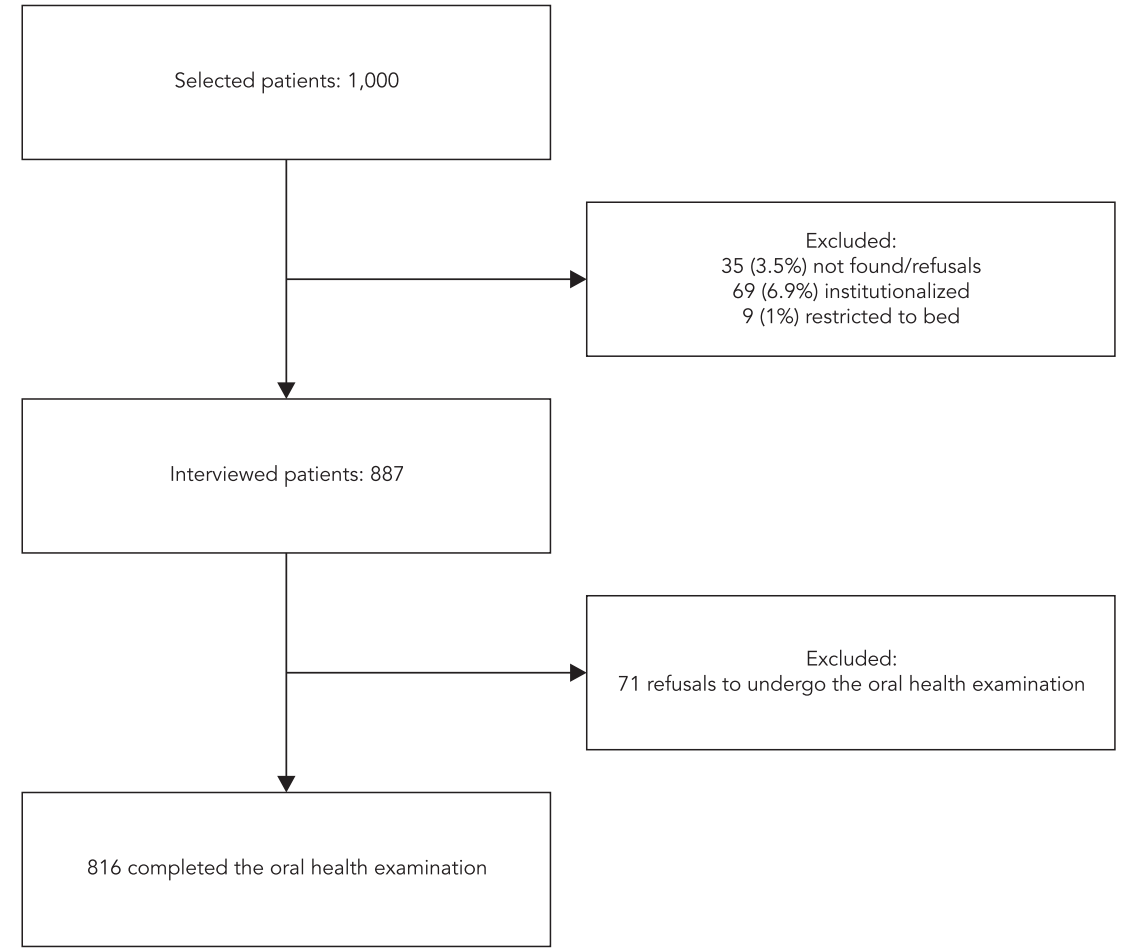

Table 1

Final logistic regression model for nutrient inadequacy in relation to the independent variables.

\begin{tabular}{|c|c|c|c|c|c|c|}
\hline \multirow[t]{2}{*}{ Nutrient } & \multicolumn{6}{|c|}{ Independent variables } \\
\hline & Gender & $\begin{array}{c}\text { Education } \\
\text { elderly } \\
\text { (years) }\end{array}$ & $\begin{array}{l}\text { Dental } \\
\text { status }\end{array}$ & POP & $\begin{array}{c}\text { Education } \\
\text { household } \\
\text { head }\end{array}$ & $\begin{array}{l}\text { Size of the } \\
\text { household }\end{array}$ \\
\hline Vitamin C & $x$ & $x$ & $x$ & $x$ & & \\
\hline Calcium & & $x$ & & $x$ & & \\
\hline Carbohydrate & $x$ & & & & $x$ & \\
\hline Iron & $x$ & $x$ & & & & \\
\hline Phosphorous & $x$ & & & & & \\
\hline Niacin & $x$ & & $x$ & & & $x$ \\
\hline Protein & $x$ & $x$ & & & & \\
\hline Riboflavin & & & & $x$ & & \\
\hline Thiamin & $x$ & $x$ & & & & \\
\hline Zinc & & & & $x$ & & \\
\hline
\end{tabular}

POP: posterior occluding pairs of natural teeth; $X$ : is equal to the statistically significant variables. 
Adjusted odds ratio (OR) and $95 \%$ confidence interval $(95 \% \mathrm{Cl})$ and final logistic regression model for inadequacy of nutrient intake in relation to the independent variables sex, education of the elderly (years) and number of posterior occluding pairs of natural teeth (POP).

\begin{tabular}{|c|c|c|c|c|c|c|c|}
\hline \multirow[t]{3}{*}{ Nutrient } & \multicolumn{7}{|c|}{ Inadequacy of nutrient intake [OR $(95 \% \mathrm{Cl})]$} \\
\hline & \multirow{2}{*}{$\begin{array}{c}\text { Gender * } \\
\text { Male }\end{array}$} & \multicolumn{4}{|c|}{ Education of the elderly (years) ** } & \multicolumn{2}{|c|}{ POP *** } \\
\hline & & $0-3$ & $4-7$ & $8-10$ & $11-14$ & 0 & $1-4$ \\
\hline Vitamin C & $1.52(1.11-2.10)$ & $9.86(3.39-28.69)$ & $6.46(2.18-19.10)$ & $4.59(1.41-14.88)$ & $2.81(0.88-8.97)$ & $2.79(1.16-6.71)$ & $1.98(0.79-4.94)$ \\
\hline Calcium & - & $9.13(3.56-23.41)$ & $7.00(2.52-19.48)$ & $4.51(1.28-15.86)$ & $2.02(0.81-5.08)$ & $3.74(1.69-8.25)$ & $1.48(0.61-3.59)$ \\
\hline Carbohydrate & $0.39(0.19-0.82)$ & - & - & - & - & - & - \\
\hline Iron & $0.42(0.26-0.68)$ & $4.35(1.02-18.54)$ & $2.68(0.61-11.83)$ & $2.38(0.47-11.95)$ & $0.99(0.18-5.37)$ & - & - \\
\hline Phosphorous & $0.37(0.25-0.54)$ & - & - & - & - & - & - \\
\hline Niacin & $0.43(0.25-0.75)$ & - & - & - & - & - & - \\
\hline Protein & $0.42(0.26-0.68)$ & $4.35(1.02-18.54)$ & $2.68(0.61-11.83)$ & $2.38(0.47-11.95)$ & $0.99(0.18-5.37)$ & - & - \\
\hline Riboflavin & - & - & - & - & - & $2.49(1.10-5.64)$ & $1.38(0.50-3.79)$ \\
\hline Thiamin & $0.60(0.41-0.88)$ & $2.41(1.15-5.05)$ & $1.93(0.88-4.19)$ & $2.31(0.86-6.20)$ & $1.13(0.49-2.61)$ & - & - \\
\hline Zinc & - & - & - & - & - & $3.43(1.07-10.94)$ & $0.87(0.24-3.08)$ \\
\hline
\end{tabular}

* Female used as a reference category;

** $\geq 15$ years used as a reference category;

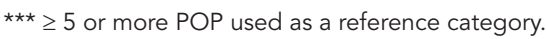

cording to the above-mentioned variables: gender, schooling of the older persons (years) and POP. The number of posterior occluding pairs of teeth was the best oral health predictor for the inadequacy of nutrient intake. People with no POP were more likely to have an inadequate intake of vitamin C (OR = 2.79; 95\%CI: 1.16-6.71), calcium (OR $=3.74$; 95\%CI: 1.69-8.25), riboflavin $(\mathrm{OR}=2.49 ; 95 \% \mathrm{CI}: 1.10-5.64)$ and zinc $(\mathrm{OR}=$ 3.43; 95\%CI: 1.07-10.94). ANOVA demonstrated that the mean number of nutrients consumed adequately was significantly related $(p=0.000)$ to the three oral health variables. The results from multiple comparison analysis revealed that the mean number of nutrients consumed adequately decreased with an increase in dentition impairment. Figure 2 shows the decrease in the mean number of nutrients consumed at an adequate level according to the number of POP. The final linear regression model showed that this variable was associated with gender $(\mathrm{p}=0.007)$, education of the elderly ( $\mathrm{p}=0.001)$ and POP $(\mathrm{p}=0.001)$.

\section{Discussion}

The results of this research showed that having no POP increases the likelihood of having an inadequate intake of vitamin $\mathrm{C}$, calcium, riboflavin and zinc. Interestingly, the relationship between oral health and diet has focused on the differences in mean nutrient intake and few studies have investigated the relationship between oral health and inadequacy of nutrient intake among elderly people. Similar to these findings, other authors 31 have observed that subjects with adequate calcium and folate intake had a higher number of teeth (and a higher number of functional teeth) than those with inadequate intakes. Conversely, Liedberg et al. 17 found no significant differences regarding number of teeth, occlusal contacts or removable dentures between those with adequate or inadequate nutrition. However, differences in the criteria used to measure both oral health and nutrient adequacy might influence the results and make it difficult to make direct comparisons.

In this study, a multiple logistic regression model was used to investigate which of the three frequent parameters of oral health (number of teeth, POP and overall dental status) is the best predictor of an inadequate nutrient intake. The bivariate analysis revealed that inadequate intake of all the nutrients, except for carbohydrate and vitamin B2, was related to at least two dental status variables. However, the concomitant inclusion of these factors in the multiple logistic regression model reduced the effect for the number of teeth to non-significance and confirmed that the number of POP was the strongest predictor of higher risk of inadequate nutrient intake. This fact suggests that the earlier association might be related to a positive association between these variables. A similar trend was observed when an- 
Mean number of nutrients consumed at adequate levels according to the number of posterior occluding pairs of natural teeth (POP).

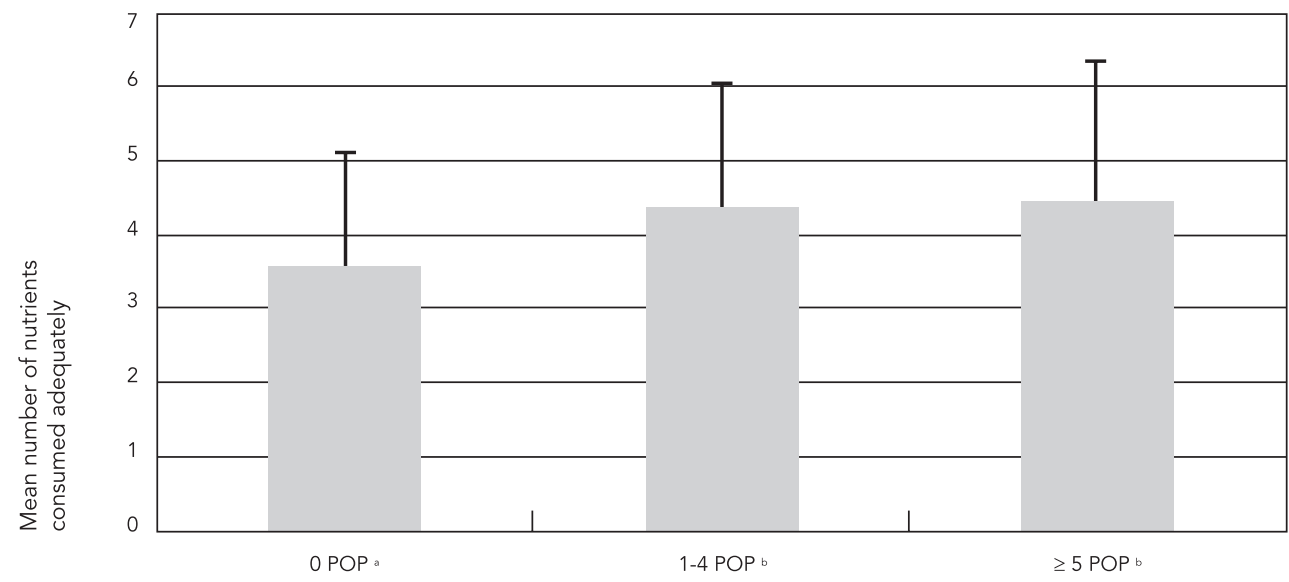

Note: different superscripts letters are significantly different at $p<0.05$.

alyzing the mean number of nutrients that were adequately consumed. When one considers that optimum health - including oral health - requires adequate intake of all nutrients, it is important to know which nutrients are adequately consumed. Thus, according to our results, it can be seen that the mean number of nutrients consumed at an adequate level was higher when the number of POP increased.

These findings expand on the existing evidence by demonstrating that more than differences between the mean intakes of important nutrients $12,37,38$, the reduced number of POP is related to a significant increase in the odds of inadequate nutrient intake. Corroborating our findings, Marcenes et al. 12 reported that the number of teeth may not be the most suitable measurement of masticatory function. Having posterior teeth that occlude may be more significant than having a few poorly distributed teeth. Hildebrant et al. 37 highlighted that the number of teeth may provide an overestimation of the masticatory potential, because such a value does not take into account the functional arrangement of the teeth. However, it is worthwhile pointing out that despite the increase in masticatory performance, prosthetic replacement is not related to significant changes in dietary quality $39,40,41,42$, when not accompanied by dietary counseling 43 .

According to the literature, diet quality 8,44 and appetite 10 are related to social support mea- sures, especially the support from family and friends. However, a strong connection with family does not necessarily result in a better outcome, particularly, in families where there is excessive control over individual members and a lack of independence or autonomy 19,45. Despite this, to our knowledge this is the first study that assesses the role of family cohesion in the inadequacy of nutrient intake. The intermediate or balanced levels of family cohesion (separated or connected) contribute to optimal family functioning; members are able to experience being both independent from and connected to their family. On the other hand, a disengaged relationship is related to extreme emotional separateness, little involvement among family members and a high level of independence. In a very connected family there is an extreme amount of emotional closeness and individuals are highly dependent upon each other 22 . In line with this thought, it was hypothesized that the unbalanced levels of cohesion were related to an increased likelihood of an inadequate intake of nutrients. However, no statistical significance was observed between family cohesion and the dependent variables. Family cohesion was even significant enough to be considered for multiple logistic regression analysis, thereby suggesting that the relationship between nutrition adequacy and social support might be more related to instrumental support (e.g. meal preparation, grocery shopping, etc) as 
well as nutrition knowledge, culture and preferences or other socio-demographic variables.

Regarding the socioeconomic variables, both years of schooling of the elderly and their gender were significantly related to the number of nutrients consumed adequately and to the inadequacy of nutrient intake. Differences between genders have been previously reported and, according to these studies, men have significantly higher intakes of nutrients than women, except for vitamin C 46,47,48, which corroborates the results found in this study. The combination of low schooling and health problems has also been described in other studies. Low educational levels have been frequently related to a decrease in dietary quality and nutrient intake 11,49. In line with this, it was observed that schooling was positively related to the mean number of nutrients consumed at an adequate level. People with $0-3$ years of schooling had a significantly increased chance of having an inadequate intake when compared with those with 15 years or more. One of the possible reasons for this might be the relationship between schooling level and both income 50 and nutrition knowledge 51. Fitzgerald et al. 51 observed that education was positively related to knowledge about nutrition and to the intake of fruits, vegetables, and meats.

It is important to consider that despite the importance of this study's results, they are limited by its cross-sectional design which only allows for association to be identified and, therefore, lacks the power to establish a cause-effect relationship. Furthermore, this study was only performed with the elderly registered in the FHP and in the CHAP, which limits the relevance of the findings for other populations. Another limit to be considered is the high proportion of women in the sample. However, according to the literature the sex ratio of the elderly population is very different and the number of women is greater than the number of men. This difference is explained by differences in life expectancy between the genders which is a worldwide phenomenon and is very intense in Brazil, where women on average live eight years longer than men. In 1991, women in Brazil accounted for $54 \%$ of the elderly, rising to $55.1 \%$ in 200052 . On this basis, the findings confirm the association between oral health and an inadequate intake of nutrients, which is also related to the schooling level and the gender of older people. Thus, it is worth highlighting the importance of tooth maintenance throughout life and the prosthetic replacement of impaired teeth, accompanied by nutritional counseling. Furthermore, considering the high prevalence of inadequate nutrition and tooth loss among this population, there is the need for effective multidisciplinary work. Since older people in Brazil have limited access to dental services 53 , nutritionists or physicians are ever more important for the evaluation of the patient. 


\section{Resumo}

Este trabalho foi realizado com o objetivo de avaliar a relação entre o consumo inadequado de nutrientes, condição de saúde bucal e coesão familiar. Foi realizado um estudo transversal com uma amostra de 887 idosos não institucionalizados da cidade de Vitória, Espírito Santo, Brasil. O exame bucal foi feito por três examinadores treinados e calibrados, e considerou três medidas: número de pares oclusais posteriores (POP), número de dentes e condição dental geral. A ingestão de nutrientes foi avaliada utilizando-se o recordatório de 24 horas. A percepção da coesão familiar foi avaliada por meio da escala de adaptabilidade e coesão familiar. Os idosos sem POP apresentaram mais chances de consumo inadequado de vitamina $C(O R=2,79$; IC95\%: 1,16-6,71), cálcio (OR = 3,74; IC95\%: 1,69-8,25), riboflavina $(O R=2,49$; IC95\%: 1,10-5,64) e zinco $(O R=$ 3,43; IC95\%: 1,07-10,94) do que aqueles com 5 ou mais. Não houve associação entre o consumo inadequado $e$ a coesão familiar. Concluiu-se que existe relação entre a condição de saúde bucal e o consumo inadequado de nutrientes importantes entre idosos não institucionalizados.

Saúde Bucal; Nutrição; Idoso; Apoio Social

\section{References}

1. Institute of Medicine. The role of nutrition in maintaining health in the nation's elderly. Washington DC: National Academy Press; 2000.

2. World Health Organization. Diet, nutrition, and the prevention of chronic diseases. Geneva: World Health Organization; 2003. (WHO Technical Report Series, 916).

3. Volkert D, Kreuel K, Heseker H, Stehle P. Energy and nutrient intake of young-old, old-old and very-old elderly in Germany. Eur J Clin Nutr 2004; 58:1119200.

4. Dauchet L, Amouyel P, Hercberg S, Dallongeville J. Fruit and vegetable consumption and risk of coronary heart disease: a meta-analysis of cohort studies. J Nutr 2006; 136:2588-93.

5. He FJ, Nowson CA, MacGregor GA. Fruit and vegetable consumption and stroke: meta-analysis of cohort studies. Lancet 2006; 367:320-6.

6. Budtz-Jøgensen E, Chung JP, Rapin CH. Nutrition and oral health. Best Pract Res Clin Gastroenterol 2001; 15:885-96.

\section{Contributors}

F. B. Andrade, A. F. Caldas Junior and P. M. Kitoko worked on the elaboration of the research project, data collection and analysis and on the conception and writing of this paper. E. Zandonade worked on the data analysis/ interpretation and on the conception of this paper.

\section{Acknowledgments}

This study was supported by the National Research Council (CNPq; grant-471391/2006-9); and the City Hall of Vitória, Espírito Santo State, Brazil.
7. World Health Organization. Keep fit for life: meeting the nutritional needs of older persons. Geneva: World Health Organization; 2002.

8. Toner HM, Morris JD. A social-psychological perspective of dietary quality in later adulthood. J Nutr Elder 1992; 11:35-53.

9. Centers for Disease Control and Prevention. Social support and health-related quality of life among older adults: Missouri, 2000. MMWR Morb Mortal Wkly Rep 2005; 54:433-7.

10. Okamoto K, Harasawa Y, Shiraishi T, Sakuma K, Momose Y. Much communication with family and appetite among elderly persons in Japan. Arch Gerontol Geriatr 2007; 45:319-26.

11. Shannon J, Shikany JM, Barrett-Connor E, Marshall LM, Bunker CH, Chan JM, et al. Demographic factors associated with the diet quality of older US men: baseline data from the Osteoporotic Fractures in Men (MrOS) study. Public Health Nutr $2007 ; 10: 810-8$ 
12. Marcenes W, Steele JG, Sheiham A, Walls AWG. The relationship between dental status, food selection, nutrient intake, nutritional status, and body mass index in older people. Cad Saúde Pública 2003; 19:809-16.

13. Andrade FB, Caldas Jr. AF, Kitoko PM. Relationship between oral health, nutrient intake and nutritional status in a sample of Brazilian elderly people. Gerodontology 2009; 26:40-5.

14. Mojon P, Budtz-Jøgensen E, Rapin C. Relationship between oral health and nutrition in very old people. Age Ageing 1999; 28:463-8.

15. Marshall TA, Stumbo PJ, Warren JJ, Xie XJ. Inadequate nutrient intakes are common and are associated with low diet variety in rural, communitydwelling elderly. J Nutr 2001; 131:2192-6.

16. Lopes ACS, Caiaffa WT, Sichieri R, Mingoti SA, Lima-Costa MF. Consumo de nutrientes em adultos e idosos em estudo de base populacional: Projeto Bambuí. Cad Saúde Pública 2005; 21:1201-9.

17. Liedberg B, Stoltze K, Norlén P, Owall B. Inadequate dietary habits and mastication in elderly men. Gerodontology 2007; 24:41-6.

18. Shaikh AR, Yaroch AL, Nebeling L, Yeh MC, Resnicow K. Psychosocial predictors of fruit and vegetable consumption in adults a review of the literature. Am J Prev Med 2008; 34:535-43.

19. Mulvaney-Day NE, Alegría M, Sribney W. Social cohesion, social support, and health among Latinos in the United States. Soc Sci Med 2007; 64:477-95.

20. Dupertuis LL, Aldwin CM, Bosse R. Does the source of support matter for different health outcomes? Findings from the Normative Aging Study. J Aging Health 2001; 13:494-510.

21. Levy-Storms L, Lubben JE. Network composition and health behaviors among older Samoan women. J Aging Health 2006; 18:814-36.

22. Olson DH. Circumplex model of marital and family systems. Journal of Family Therapy 2000; 22: 144-67.

23. Kouneski EF. The family model, FACES II and FACES III: overview of research and applications. St. Paul: University of Minnesota; 2000.

24. Bartali B, Frongillo EA, Bandinelli S, Lauretani F, Semba RD, Fried LP, et al. Low nutrient intake is an essential component of frailty in older persons. J Gerontol A Biol Sci Med Sci 2006; 61:589-93.

25. Michelon E, Blaum C, Semba RD, Xue QL, Ricks MO, Fried LP. Vitamin and carotenoid status in older women: associations with the frailty syndrome. J Gerontol A Biol Sci Med Sci 2006; 61:600-7.

26. Olson DH, Portner J, Lavee Y. FACES III (Family Adaptability and Cohesion Evaluation Scales). St. Paul: University of Minnesota; 1985.

27. World Health Organization. Oral health surveys: basic methods. $4^{\text {th }}$ Ed. Geneva: World Health Organization; 1997.

28. Finch SA, Doyle W, Lowe C, Bates CJ, Prentice A, Smithers G, et al. National Diet and Nutrition Survey: people aged 65 years and over, 1994-1995. 2nd Ed. Colchester: UK Data Archive, University of Essex; 2001. (UKDA Study Number, 4036).

29. Thompson FE, Byers T. Dietary assessment resource manual. J Nutr 1994; 124(11 Suppl):2245S317 S.
30. Holmes B, Dick K, Nelson M. A comparison of four dietary assessment methods in materially deprived households in England. Public Health Nutr 2008; 11:444-56.

31. Marshall TA, Warren JJ, Hand JS, Xie XJ, Stumbo PJ. Oral health, nutrient intake and dietary quality in the very old. J Am Dent Assoc 2002; 133:1369-79.

32. Institute of Medicine. Dietary reference intakes for calcium, phosphorus, magnesium, vitamin D, and fluoride. Washington DC: National Academy Press; 1997.

33. Institute of Medicine. Dietary reference intake for vitamin $\mathrm{C}$, vitamin $\mathrm{E}$, selenium, and carotenoids. Washington DC: National Academy Press; 2000.

34. National Research Council. Recommended dietary allowances. 10 ${ }^{\text {th }}$ Ed. Washington DC: National Academy Press; 1989.

35. Institute of Medicine. Dietary Reference intakes for energy, carbohydrate, fiber, fat, fatty acids, cholesterol, protein, and amino acids (macronutrients). Washington DC: National Academy Press; 2005.

36. Institute of Medicine. Dietary reference intakes for vitamin A, vitamin $\mathrm{K}$, arsenic, boron, chromium, copper, iodine, iron, manganese, molybdenum, nickel, silicon, vanadium and zinc. Washington DC: National Academy Press; 2000.

37. Hildebrandt GH, Dominguez BL, Schork MA, Loesche WJ. Functional units, chewing, swallowing, and food avoidance among elderly. J Prosthet Dent 1997; 77:588-95.

38. Sheiham A, Steele JG, Marcenes W, Lowe C, Finch $\mathrm{S}$, Bates CJ, et al. The relationship among dental status, nutrient intake, and nutritional status in older people. J Dent Res 2001; 80:408-13.

39. Moynihan PJ, Butler TJ, Thomason JM, Jepson NJ. Nutrient intake in partially dentate patients: the effect of prosthetic rehabilitation. J Dent 2000; 28:557-63.

40. Allen F, McMillan A. Food selection and perceptions of chewing ability following provision of implant and conventional prostheses in complete denture wearers. Clin Oral Implants Res 2002; 13:320-6.

41. Liedberg B, Norlén P, Owall B, Stoltze K. Masticatory and nutritional aspects on fixed and removable partial dentures. Clin Oral Investig 2004; 8:11-7.

42. Muller K, Morais J, Feine J. Nutritional and anthropometric analysis of edentulous patients wearing implant overdentures or conventional dentures. Braz Dent J 2008; 19:145-50.

43. Bradbury J, Thomason JM, Jepson NJ, Walls AW, Allen PF, Moynihan PJ. Nutrition counseling increases fruit and vegetable intake in the edentulous. J Dent Res 2006; 85:463-8.

44. Donkin AJ, Johnson AE, Morgan K, Neale RJ, Page RM, Silburn RL. Gender and living alone as determinants of fruit and vegetable consumption among the elderly living at home in urban Nottingham. Appetite 1998; 30:39-51.

45. Kawachi I, Berkman LF. Social ties and mental health. J Urban Health 2001; 78:458-67.

46. Weimer J. Factors affecting nutrient intake of the elderly. Washington DC: U.S. Department of Agriculture; 1998. (Agricultural Economic Report, 769). 
47. Cid-Ruzafa J, Caulfield LE, Barrón Y, West SK. Nutrient intakes and adequacy among an older population on the eastern shore of Maryland: the Salisbury Eye Evaluation. J Am Diet Assoc 1999; 99: 564-71.

48. Friel S, Kelleher CC, Nolan G, Harrington J. Social diversity of Irish adults nutritional intake. Eur J Clin Nutr 2003; 57:865-75.

49. Reidiger ND, Moghadasian MH. Patterns of fruit and vegetable consumption and the influence of sex, age and socio-demographic factors among Canadian elderly. J Am Coll Nutr 2008; 27:306-13.

50. Instituto Brasileiro de Geografia Estatística. Síntese de indicadores sociais: uma análise das condições de vida da população brasileira 2007. Rio de Janeiro: Instituto Brasileiro de Geografia Estatística; 2007. (Estudos e Pesquisas. Informação Demográfica e Socioeconômica, 21).
51. Fitzgerald N, Damio G, Segura-Pérez S, PérezEscamilla R. Nutrition knowledge, food label use, and food intake patterns among Latinas with and without type 2 diabetes. J Am Diet Assoc 2008; 108:960-7.

52. Instituto Brasileiro de Geografia Estatística. Perfil dos idosos responsáveis pelos domicílios no Brasil 2000. Rio de Janeiro: Instituto Brasileiro de Geografia Estatística; 2002.

53. Instituto Brasileiro de Geografia Estatística. Pesquisa Nacional por Amostra de Domicílios: acesso e utilização de serviços de saúde, 2003. Rio de Janeiro: Instituto Brasileiro de Geografia Estatística; 2005.

Submitted on $05 /$ Sep/2009

Final version resubmitted on 22/Aug/2010 Approved on 24/Aug/2010 